\title{
Response of the jejunal mucosa in adult coeliac disease to oral prednisolone
}

\author{
ALFRED J. WALL ${ }^{1}$, ADRIAN P. DOUGLAS ${ }^{2}$, C. C. BOOTH, \\ AND A. G. E. PEARSE \\ From the Departments of Medicine and Pathology, and the MRC Intestinal Malabsorption Group, \\ Royal Postgraduate Medical School, London
}

SUMMARY Five patients with adult coeliac disease were treated with prednisolone for four to five weeks while continuing a normal gluten-containing diet. A prompt histological, ultrastructural and enzymic recovery of the jejunal mucosa in all five was accompanied by an incomplete metabolic response in three of four patients tested. These findings are discussed in relation to the possible immunological pathogenesis of coeliac disease.

It is known that patients with adult coeliac disease will respond clinically to either a glutenfree diet (French, Hawkins, and Smith, 1957) or to oral corticosteroids (Adlersberg, Colcher, and Drachman, 1951; Lepore, 1958). Several studies have demonstrated histological and histochemical improvement of the jejunal mucosa in adult coeliac patients taking a gluten-free diet (Yardley, Bayless, Norton, and Hendrix, 1962; MacDonald, Brandborg, Flick, Trier, and Rubin, 1964; Benson, Kowlessar, and Sleisenger, 1964; Spiro, Filipe, Stewart, Booth, and Pearse, 1964; Samloff, Davis, and Schenk, 1965; Riecken, Stewart, Booth, and Pearse, 1966). Comparable studies during corticosteroid therapy have not hitherto been reported.

Riecken et al (1966) in their histochemical studies confirmed the earlier observations by Spiro et al (1964) that in the mucosa from patients with untreated adult coeliac disease the lysosomal enzymes were dispersed widely throughout the cytoplasm of the epithelial cells, possibly as a result of disruption of the lysosomal membrane by the toxic factor in gluten. In mucosa from patients with treated adult coeliac disease the lysosomal membranes appeared to have been reconstituted. Riecken and his colleagues (1966)

1Supported by a Commonwealth medical fellowship and the Wellcome Trust.

${ }^{2}$ MRC clinical research fellow. suggested a possible fundamental role of the lysosomes in the development of the lesions of the surface epithelium in coeliac disease. The observation that corticosteroids apparently stabilize lysosomal membranes (Weissmann, 1964) may explain the beneficial action of corticosteroids in coeliac disease.

The present investigation concerns the response of the jejunal mucosa in adult coeliac disease to oral prednisolone while the patient continues a normal diet. Histological, histochemical, and biochemical changes have been measured and the mechanisms concerned in the response of the mucosa are discussed.

\section{Materials and Methods}

\section{PATIENTS}

Five patients with untreated adult coeliac disease who were taking a normal diet were studied. Four were males and one female, and ages ranged from 29 to 66 years. All presented with anaemia and folic acid deficiency. Four had steatorrhoea at the time of the study. All patients have subsequently been shown to respond to a gluten-free diet. 
Alfred J. Wall, Adrian P. Douglas, C. C. Booth, and A. G. E. Pearse

prednisolone was given by mouth four times daily for four to five weeks, and then gradually withdrawn over 10 days. A normal diet was given throughout the period of study.

JEJUNAL BIOPSY

Under fluoroscopic control the Crosby capsule (Crosby and Kugler, 1957) was used to biopsy mucosa from immediately past the ligament of Treitz. The biopsy was divided and processed as follows:

\section{Light microscopy}

After mounting on a coverslip and immersion in $15 \%$ formol saline, the biopsy was examined under a dissecting microscope and photographed. After careful orientation to ensure that the tissue was sectioned vertical to the surface it was processed to paraffin sections each of 6 to $8 \mu$. Haematoxylin and eosin and PAS stains were used. Measurements were made using an ocular micrometer. Villous height was measured from the tip of a mucosal projection to the mouth of the crypt. 'Villi' broader than $200 \mu$ were excluded from measurement. Mucosal thickness was measured from the mouth of the crypt to the inner margin of the muscularis mucosa in 10 sites. Cell height of the surface epithelium was measured, away from the crypt mouth, using 50 randomly selected surface cells along the length of the section. Lymphoid cell infiltration of the mucosa was graded in intensity from 0 to 3 , where 1 represents normal and 3 a heavy infiltrate.

\section{Electron microscopy}

Four to six biopsy fragments were immediately immersed in buffered $1 \% \mathrm{OsO}_{4}$ at $4{ }^{\circ} \mathrm{C}$, fixed for one hour at $4^{\circ} \mathrm{C}$, processed and embedded in araldite epoxy resin. Sections were cut at 500 to $600 \AA$ thickness, stained with uranyl acetate and lead citrate, and examined with an EM 6 B electron microscope.

\section{Histochemistry}

The biopsy was supported by a cube of rat liver and immediately quenched in liquid nitrogen. Specimens were stored in liquid nitrogen before cryostat sectioning at $-20^{\circ} \mathrm{C}$. Sections, $8 \mu$ in thickness, were picked up on coverslips and fixed, before incubation, in acetone at $4^{\circ} \mathrm{C}$ or, after incubation, in $15 \%$ formol saline. Methyl green and Mayer's carmalum were used as counterstains, and sections were mounted in glycerine jelly or DPX. The series of biopsies from each patient were incubated simultaneously together with a normal control.

The following enzyme methods were used: alkaline phosphatase (Burstone, 1958); adenosine triphosphatase (ATPase) (Wachstein and Meisel, 1957); aminopeptidase'(LAP)(Nachlas, Crawford, and Seligman, 1957); acid phosphatase (Gomori,
1952; Barka and Anderson, 1962); betaglucuronidase (Pugh and Walker, 1961); E-600 resistant esterase (Hess and Pearse, 1958); substrate 5 bromo-4 chloroindoxyl-acetate; succinic dehydrogenase (Nachlas, Tsou, Souza, Cheng, and Seligman, 1957); nicotine adenine dinucleotide (NADH) diaphorase and nicotine adenine dinucleotide phosphate (NADPH) diaphorase (Scarpelli, Hess, and Pearse, 1958); monoamine oxidase (Glenner, Burtner, and Brown, 1957); aldolase (Abe and Shimizu, 1964); glucose-6-phosphatase (Wachstein and Meisel, 1956); non-specific esterase (Holt, 1958). The intensity of the reaction was recorded as 0 to 4 , where 3 represents normal and 4 above normal activity.

\section{TISSUE BIOCHEMISTRY}

The biopsy was snap frozen in a sealed container in liquid nitrogen and stored at $-70^{\circ} \mathrm{C}$. The tissue was homogenized with water in a glass homogenizer and incubated for one hour at $37^{\circ} \mathrm{C}$ with a peptic-tryptic digest of gluten. Peptidase activity was estimated by measuring the release of aminoacids using an ion-exchange chromatographic system (Technicon Instruments Co. Ltd.), and the results are expressed in micro-moles of aminoacid released per milligram of protein. Protein was measured by the method of Lowry, Rosebrough, Farr, and Randall (1951). A full account of the methods used is given elsewhere (Douglas and Booth, 1970).

\section{METABOLIC STUDIES}

Patients were given a diet containing $70 \mathrm{~g}$ fat, $70 \mathrm{~g}$ protein, and normal quantities of gluten. Faecal fat and nitrogen were estimated by the method of Wooton (1964).

Chromium sesquioxide was used as an internal marker (Whitby and Lang, 1960) during a five-day equilibration period and a six-day faecal collection. Normal subjects excrete less than $6 \mathrm{~g}$ of fat and less than $2 \mathrm{~g}$ of nitrogen per day. D-xylose absorption was measured by the method of Roe and Rice (1948) using an oral dose of $25 \mathrm{~g}$ xylose. Normal subjects excrete more than $5 \mathrm{~g}$ in the urine in five hours.

\section{Results}

\section{HISTOLOGY}

The results of the histological measurements are summarized in Table I. Cell height improved in all cases during treatment, and in cases 1,2 , and 5 the 'flat' biopsy became 'convoluted' in appearance (Figs. 1a and b). After two days of treatment, surface cell height rose by $6.5 \mu$ in case 1 and by $7 \cdot 9 \mu$ in case 3 . Normal cell height $(729 \cdot 3 \mu)$, as described by Stewart, Pollock, 
Response of the jejunal mucosa in adult coeliac disease to oral prednisolone

\begin{tabular}{|c|c|c|c|c|c|c|}
\hline $\begin{array}{l}\text { Case } \\
\text { No. }\end{array}$ & $\begin{array}{l}\text { Measurement Related } \\
\text { to Duration of } \\
\text { Treatment }\end{array}$ & $\begin{array}{l}\text { Macroscopic } \\
\text { Appearance }\end{array}$ & $\begin{array}{l}\text { Cell Height } \\
(N>29 \cdot 3 \mu)\end{array}$ & $\begin{array}{l}\text { Villous Height } \\
(N>330 \mu)\end{array}$ & $\begin{array}{l}\text { Mucosal } \\
\text { Thickness } \\
(N<170 \mu)\end{array}$ & $\begin{array}{l}\text { Lymphoid } \\
\text { Infiltration } \\
(N=1)\end{array}$ \\
\hline 1 & $\begin{array}{l}a \\
b \\
c \\
d\end{array}$ & $\begin{array}{l}\text { Flat } \\
\text { Flat with mosaic } \\
\text { Convoluted } \\
\text { Flat }\end{array}$ & $\begin{array}{l}11 \cdot 5 \\
25 \cdot 1 \\
27 \cdot 2 \\
19 \cdot 6\end{array}$ & $\begin{array}{l}\text { Not measurable } \\
165 \\
167 \\
130\end{array}$ & $\begin{array}{l}306 \\
156 \\
164 \\
170\end{array}$ & $\begin{array}{l}2 \\
1 \\
1 \\
2\end{array}$ \\
\hline 2 & $\begin{array}{l}\mathbf{a} \\
\mathbf{b} \\
\mathbf{c} \\
\mathbf{d}\end{array}$ & $\begin{array}{l}\text { Flat } \\
\text { Flat } \\
\text { Convoluted } \\
\text { Flat }\end{array}$ & $\begin{array}{l}14 \cdot 9 \\
20 \cdot 1 \\
21 \cdot 5 \\
17 \cdot 8\end{array}$ & $\begin{array}{l}\text { Not measurable } \\
100 \\
99 \\
136\end{array}$ & $\begin{array}{l}272 \\
169 \\
181 \\
267\end{array}$ & $\begin{array}{l}2 \\
2 \\
1 \\
2\end{array}$ \\
\hline 3 & $\begin{array}{l}\mathbf{a} \\
\mathbf{b} \\
\mathbf{c} \\
\mathbf{d}\end{array}$ & $\begin{array}{l}\text { Flat } \\
\text { Flat } \\
\text { Flat with mosaic } \\
\text { Flat }\end{array}$ & $\begin{array}{l}14 \cdot 4 \\
25 \cdot 1 \\
25 \cdot 1 \\
22 \cdot 2\end{array}$ & $\begin{array}{l}94 \\
\text { Not measurable } \\
115 \\
\text { Not measurable }\end{array}$ & $\begin{array}{l}263 \\
460 \\
296 \\
400\end{array}$ & $\begin{array}{l}3 \\
3 \\
1 \\
2\end{array}$ \\
\hline 4 & $\begin{array}{l}\text { a } \\
b \\
\text { c } \\
\text { d }\end{array}$ & $\begin{array}{l}\text { Flat } \\
\text { Flat with mosaic } \\
\text { Flat with ridges } \\
\text { Flat }\end{array}$ & $\begin{array}{l}19 \cdot 9 \\
30 \cdot 1 \\
27 \cdot 8 \\
20 \cdot 4\end{array}$ & $\begin{array}{l}158 \\
174 \\
193 \\
\text { Not measurable }\end{array}$ & $\begin{array}{l}258 \\
206 \\
197 \\
300\end{array}$ & $\begin{array}{l}3 \\
2 \\
2 \\
3\end{array}$ \\
\hline 5 & $\begin{array}{l}\mathbf{a} \\
\mathbf{b} \\
\mathbf{c}\end{array}$ & $\begin{array}{l}\text { Flat } \\
\text { Flat } \\
\text { Convoluted }\end{array}$ & $\begin{array}{l}18 \cdot 9 \\
27 \cdot 2 \\
26 \cdot 8\end{array}$ & $\begin{array}{l}\text { Not measurable } \\
177 \\
204\end{array}$ & $\begin{array}{l}375 \\
252 \\
158\end{array}$ & $\begin{array}{l}2 \\
2 \\
1\end{array}$ \\
\hline
\end{tabular}

Table I Mucosal cell height, villous height and mucosal thickness (a) before, (b) after two weeks, (c) four to five weeks of treatment, and (d) two to four weeks after withdrawal of prednisolone
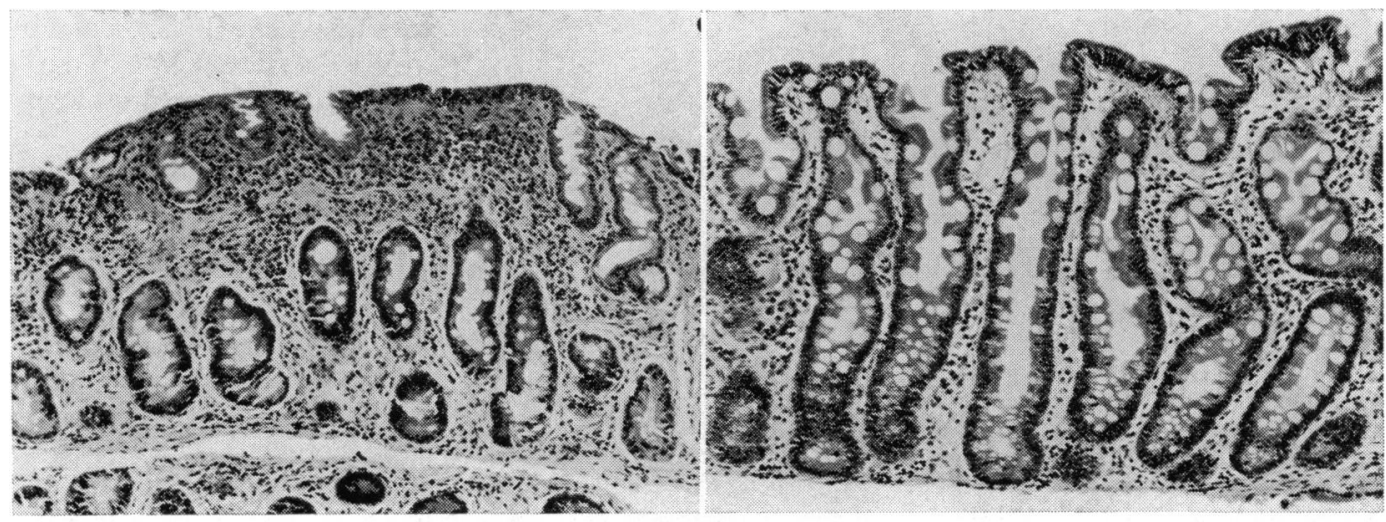

(a)

(b)

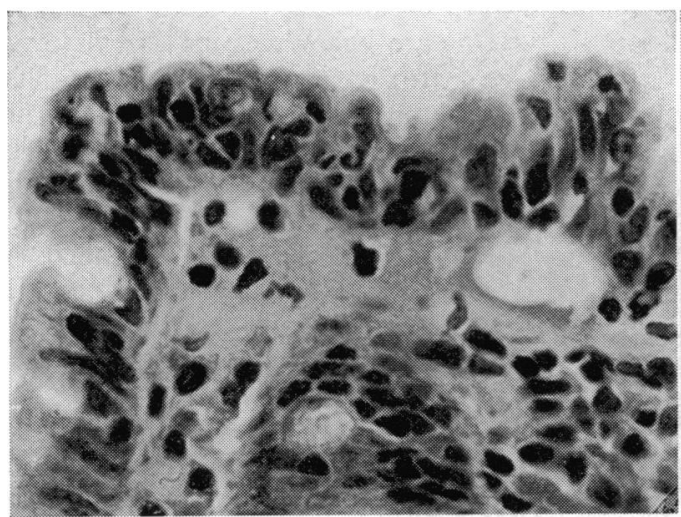

(a)

Fig. 1 (above) Jejunal biopsy specimens (a) before treatment and (b) after four weeks on oral prednisolone to show the change in mucosal architecture and diminution in lymphoid infiltration following treatment (haematoxylin and eosin $\times 130$ ).

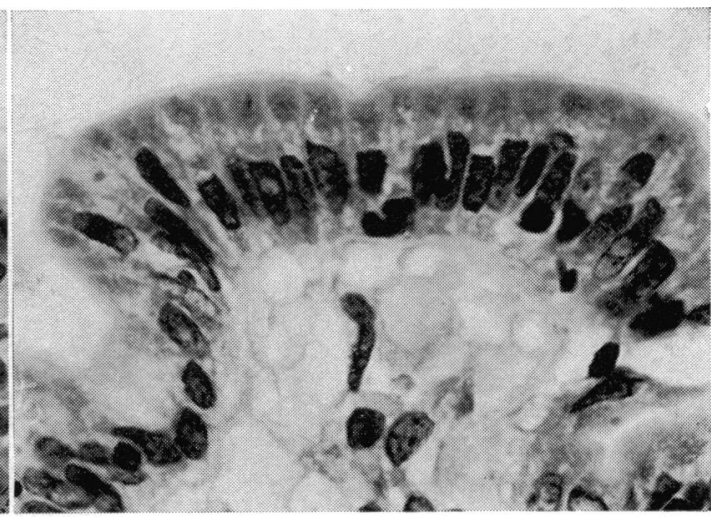

(b)

Fig. 2 (below) High-power view of surface epithelial cells in the jejunal mucosa from case 4: (a) before treatment and (b) after five weeks' oral prednisolone (haematoxylin and eosin $\times 1,000$ ). 
Hoffbrand, Mollin, and Booth, (1967) was reached by only one patient (case 4) and is shown in Figures $2 a$ and $b$. The lymphoid infiltrate became less intense during treatment in all subjects. Within four weeks of prednisolone being withdrawn, cell height fell in the four cases then studied (although not to pretreatment levels) and the lymphoid infiltrate increased.

\section{ELECTRON MICROSCOPY}

Before treatment, microvilli of surface cells were blunted, fused, and reduced in number, mitochondria were swollen and lacking in cristae, and cell nuclei were irregular in shape and position (Fig. 3a). Microvilli were normal in the initial biopsy of one patient (case 4), but were abnormal in a biopsy taken after two days of treatment. During treatment, partial recovery of the microvilli, mitochondria, and cell nuclei could be seen
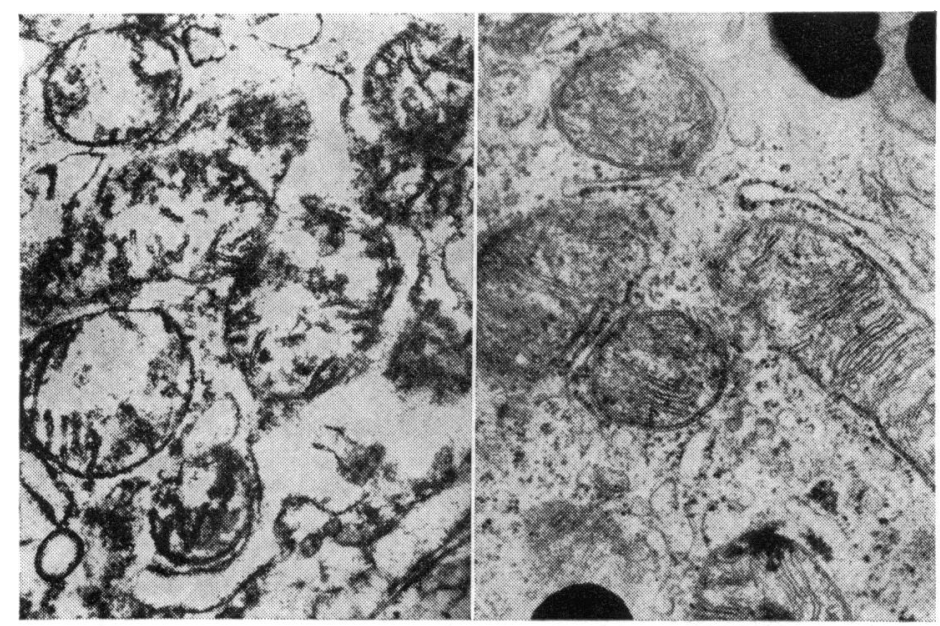

(a)

(b)
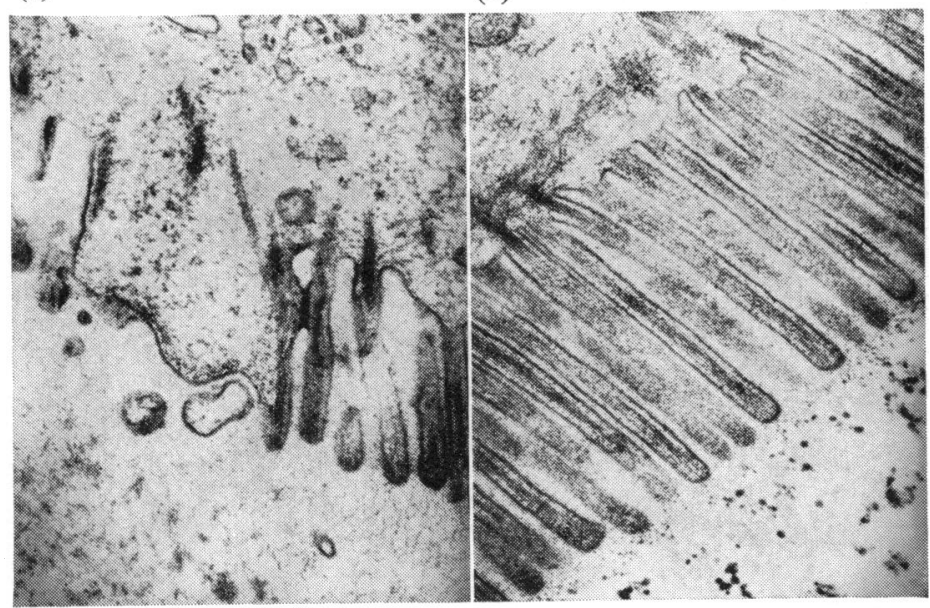

(a

(b)

Fig. 3 Electron micrographs (left) before and (right) after treatment showing restoration of microvillous structure and mitochondrial cristae after treatment $(\times 40,000)$. by two weeks (Fig. 3b, and by the end of treatment three patients had fully recovered. In cases 1 and 2 mitochondria, although improved, still appeared swollen and lacked cristae. There was no change in the numbers of lysosomes present during treatment compared with the pretreatment numbers. Following withdrawal of prednisolone, surface cells reverted to their pretreatment appearances.

\section{HISTOCHEMISTRY}

Results of enzyme histochemistry are summarized in Table II. Brush border enzymes were reduced in a patchy manner, and recovered rapidly after treatment. This is shown for alkaline phosphatase (Figs. 4a and b) and for non-specific esterase (Figs. 5a and b). The latter is regarded as mainly microsomal. There was an equally rapid return towards the normal state in mitochondrial enzyme levels, as indicated by the restoration of monoamine oxidase (MAO) which is shown in Figures $6 \mathrm{a}$ and $\mathrm{b}$. Lysosomal acid phosphatase staining was initially diffuse in four of the five patients. It rapidly assumed the normal particulate pattern with treatment (Figs. 7a and $b$ ) and these changes were seen as early as two days after commencing treatment with prednisolone in case 1. After prednisolone had been withdrawn, enzyme histochemical activity reverted to the pretreatment pattern.

\section{TISSUE BIOCHEMISTRY}

The results obtained for the measurements of the release of aminoacids from a peptic-tryptic digest of gluten by the jejunal mucosa are shown in Figure 8. Values are only shown for proline and glutamic acid release (these two aminoacids are the major constituents of the gluten peptides) but similar results were obtained for the other 11 aminoacids studied. Proline and glutamic acid are believed to be the major constituents of the toxic fraction of gluten. The activity of the mucosa as measured by the ability to digest the gluten peptide solution further improved rapidly in the four patients studied, and became normal. In two patients following withdrawal of prednisolone the ability of the mucosa to liberate aminoacids from the gluten peptides reverted to that found before treatment.

METABOLIC STUDIES

Results of metabolic studies are summarized in Table III. Four patients were studied. Xylose absorption improved in all and faecal fat and nitrogen excretion fell in all. Only in case 2 did steatorrhoea remit completely. 


\begin{tabular}{|c|c|c|c|c|c|c|c|c|c|c|c|c|c|c|}
\hline \multirow[t]{2}{*}{$\begin{array}{l}\text { Case } \\
\text { No. }\end{array}$} & \multirow[t]{2}{*}{$\begin{array}{l}\text { Time Related } \\
\text { to Treatment }\end{array}$} & \multicolumn{3}{|c|}{ Brush Border Enzymes } & \multicolumn{3}{|c|}{$\begin{array}{l}\text { Lysosomal } \\
\text { Enz ymes }\end{array}$} & \multicolumn{3}{|c|}{ Mitochondrial Enzymes } & \multicolumn{2}{|c|}{$\begin{array}{l}\text { Microsomal } \\
\text { Enzymes }\end{array}$} & \multicolumn{2}{|l|}{$\begin{array}{l}\text { Cell } \\
\text { Sap }\end{array}$} \\
\hline & & $\begin{array}{l}\text { Alkaline } \\
\text { Phosphate }\end{array}$ & $L A P$ & ATPase & $A c P$ & B-glucose & $\begin{array}{l}E-600 \\
\text { esterase }\end{array}$ & $\begin{array}{l}\text { NADH } \\
\text { Diaphorase }\end{array}$ & $\begin{array}{l}\text { NADPH } \\
\text { Diaphorase }\end{array}$ & $\begin{array}{l}\text { Succinic } \\
\text { Dehydrogenase }\end{array}$ & $M A O$ & DSE & $G-6 P D$ & Aldolase \\
\hline \multirow[t]{3}{*}{1} & $\mathbf{a}$ & 3 & 2 & 3 & 2 & 3 & - & 2 & 2 & 0 & - & 2 & 3 & - \\
\hline & b & 3 & 3 & 3 & 3 & 3 & - & 3 & 3 & 1 & - & 3 & 3 & - \\
\hline & c & 3 & 3 & 3 & 3 & 3 & - & 3 & 3 & 2 & - & 3 & 3 & - \\
\hline \multirow[t]{3}{*}{2} & $\mathbf{a}$ & 2 & 1 & 1 & 2 & 3 & - & - & - & - & 1 & 2 & 1 & 2 \\
\hline & $\vec{b}$ & 3 & 3 & 3 & 3 & 3 & - & - & - & - & 3 & 3 & 3 & 3 \\
\hline & c & 3 & 3 & 2 & 4 & 3 & 一 & - & - & - & 3 & 3 & 3 & 3 \\
\hline \multirow[t]{3}{*}{3} & $\mathbf{a}$ & 3 & 2 & 1 & 3 & 3 & - & 2 & 2 & 2 & 2 & 2 & 3 & 1 \\
\hline & b & 3 & 2 & 1 & 3 & 3 & - & 2 & 2 & 2 & 3 & 3 & 3 & 3 \\
\hline & c & 3 & 3 & 3 & 3 & 3 & - & 3 & 3 & 3 & 3 & 3 & 3 & 3 \\
\hline \multirow[t]{3}{*}{4} & $\mathbf{a}$ & 3 & 2 & 1 & 2 & 3 & 3 & 2 & 2 & 3 & 1 & 1 & 2 & 2 \\
\hline & b & 4 & 3 & 1 & 2 & 3 & 3 & 3 & 3 & 3 & 2 & 3 & 3 & 3 \\
\hline & c & 3 & 2 & 3 & 2 & 3 & 3 & 3 & 1 & 3 & 3 & 2 & 3 & 3 \\
\hline \multirow[t]{3}{*}{5} & $\mathbf{a}$ & 1 & 1 & - & 3 & 3 & - & 1 & 1 & 1 & 1 & 3 & 3 & - \\
\hline & b & 2 & 2 & - & 3 & 3 & - & 2 & 2 & 2 & 2 & 3 & 2 & - \\
\hline & c & 3 & 3 & - & 3 & 3 & - & 3 & 3 & 3 & 3 & 3 & 2 & - \\
\hline
\end{tabular}

Table II Scoring of histochemical activity of jejunal mucosa (a) before, (b) after two weeks, and (c) four to five weeks of treatment ${ }^{1}$

${ }^{1}$ Numerical score represents intensity of enzyme reaction: 3 represents normal.

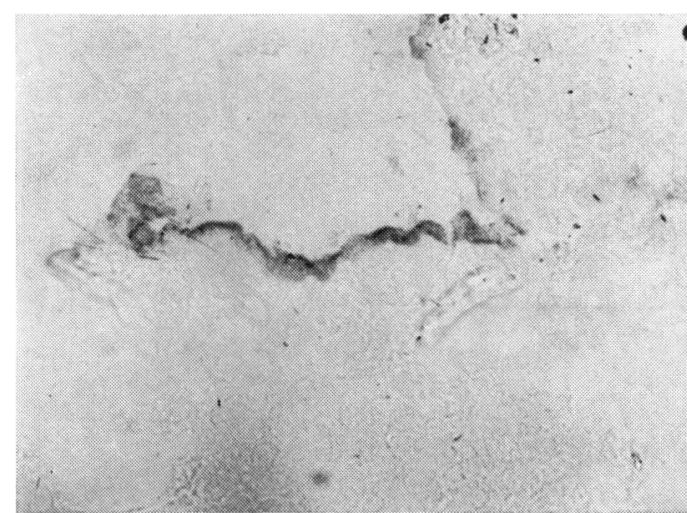

(a)

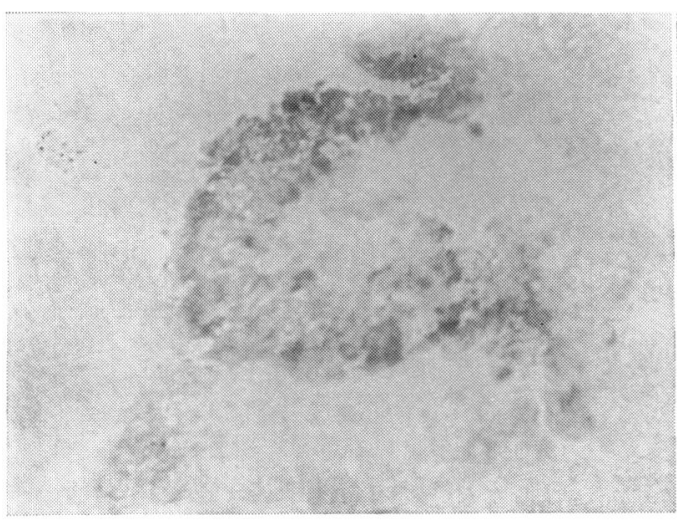

(a)

Figs. 4a and b (above). Return of alkaline phosphatase to normal levels following treatment (Azo dye method $\times 520$ ).

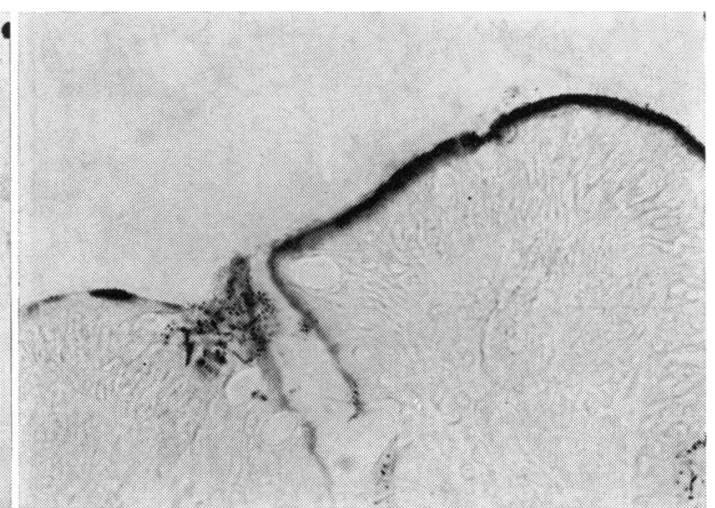

(b)

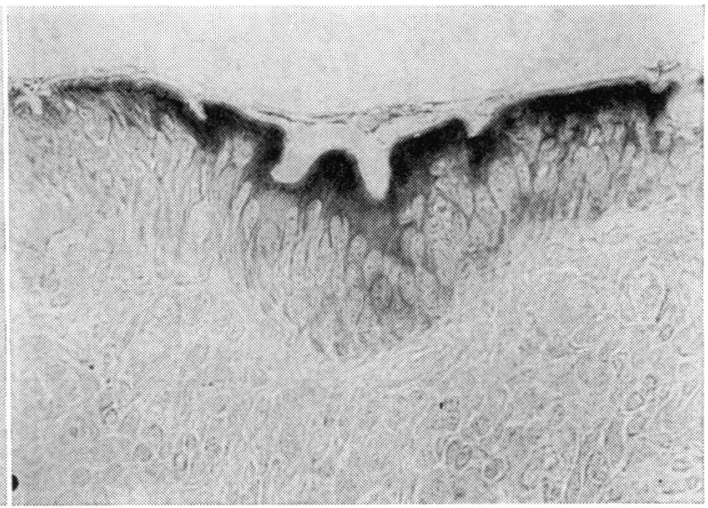

(b)
Figs. 5a and b (below). Restoration of microsomal non-specific esterase after treatment (indoxyl esterase method $\times 520$ ). 


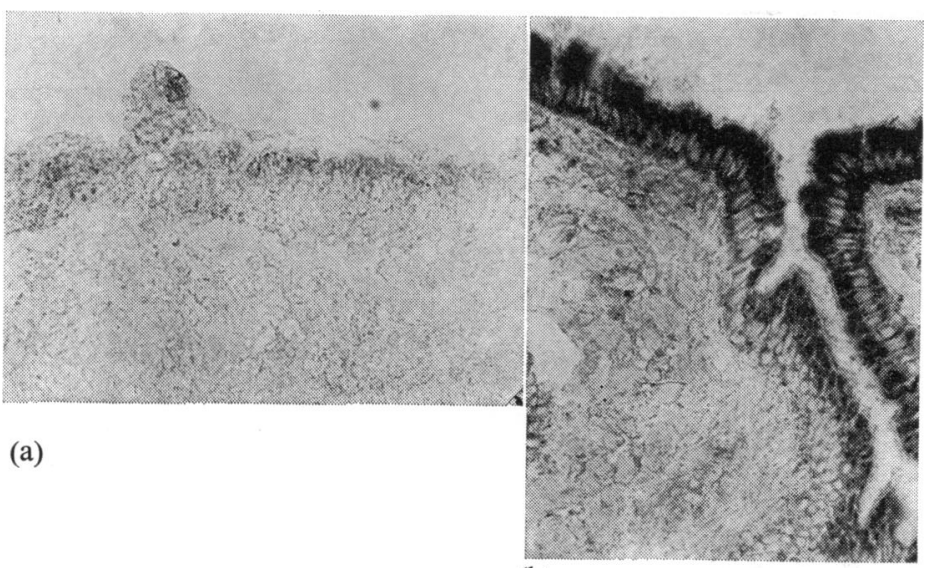

(b)

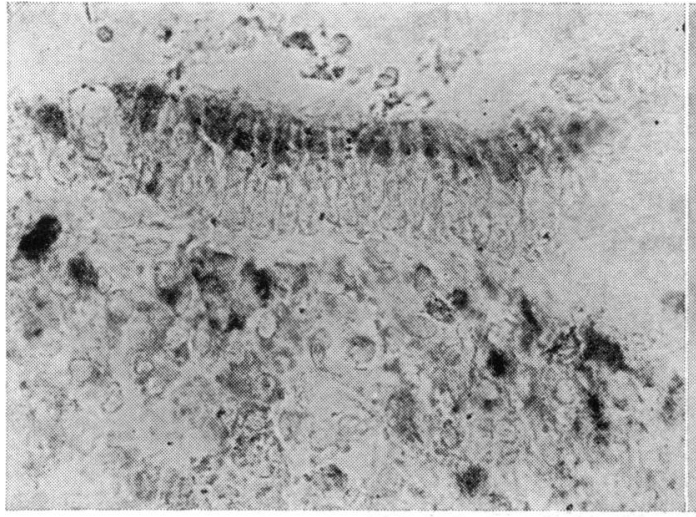

(a)

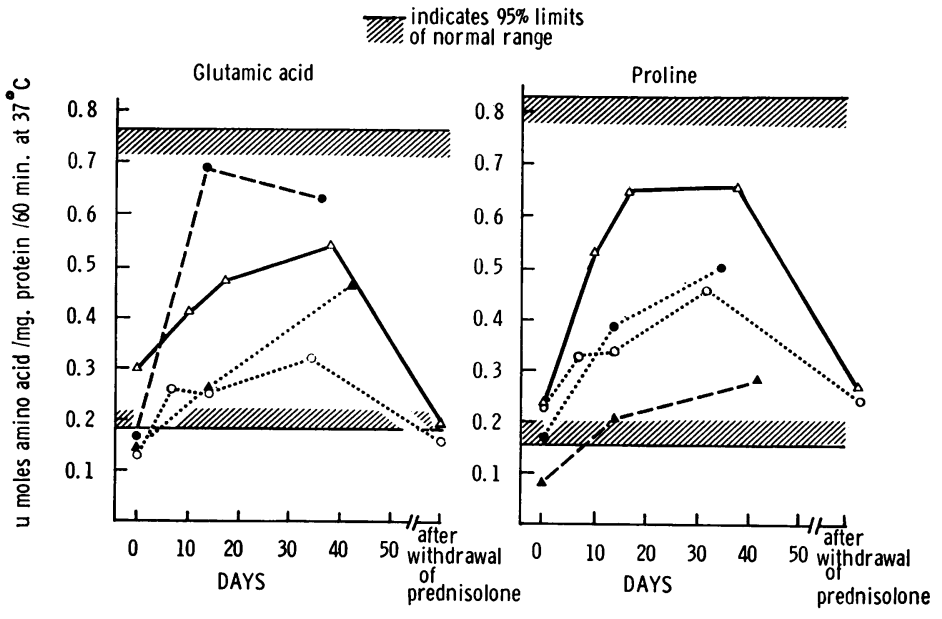

that the prednisolone was absorbed. In one patient (case 1) withdrawal of prednisolone was followed by a severe relapse with weight loss, diarrhoea, and increased steatorrhoea. The situation resembled that seen when a patient with coeliac disease in remission is exposed again to gluten and requires the reintroduction of steroid therapy together with a gluten-free diet.
Figs. $6 \mathrm{a}$ and $\mathrm{b}$ (left) Return to normal high level of monoamine oxidase in the epithelial cells of the jejunal mucosa (Tetranitro - B.T. $\times 520$ ).

Figs. $7 \mathrm{a}$ and $\mathrm{b}$ (below) Change in lysosomal acid phosphatase with treatment and return to normal pattern (Gomori method $\times 520$ ).

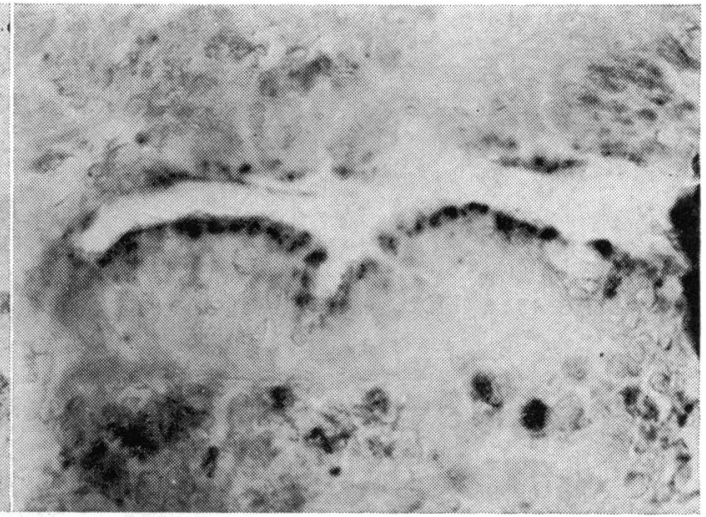

(b)

Fig. 8 Response to oral prednisolone in adult coeliac disease: the ability of jejunal mucosa to liberate amino acids from a peptic-tryptic digest of gluten.

Our patient was subsequently weaned from steroids and continued on a gluten-free diet.

\section{Discussion}

This study demonstrates the rapid histological and enzymic recovery shown in serial jejunal mucosal 
Response of the jejunal mucosa in adult coeliac disease to oral prednisolone

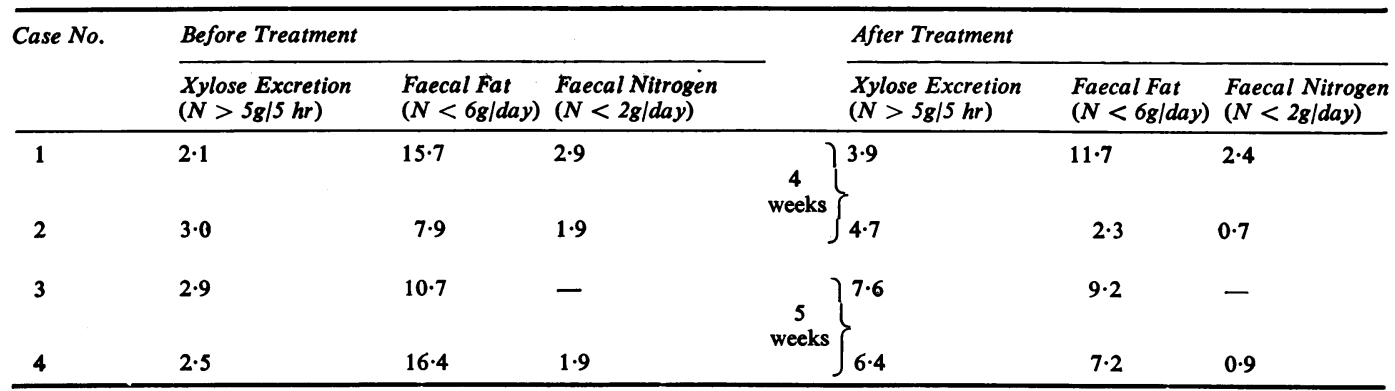

Table III Studies of intestinal absorption before and at completion of treatment with prednisolone

biopsies from five patients with adult coeliac disease who were treated with prednisolone by mouth while continuing to eat a normal diet. Relapse was rapid when the drug was withdrawn. These findings resemble closely the recovery seen in patients with coeliac disease who take a glutenfree diet (Yardley et al, 1962; Spiro et al, 1964; Riecken et al, 1966). Corticosteroids have been used in the treatment of adult coeliac disease (Adlersberg et al, 1951; Lepore, 1958; Otaki, Daly, and Morton-Gill, 1967). However, the introduction of the gluten-free diet (Dicke, 1950) has led to these drugs being seldom used, and their mode of action has remained unexplained. The accurate documentation of patients' responses to corticosteroids has now enabled adequate comparisons to be made with the effects of a gluten-free diet.

The differences between treatment with prednisolone and with diets are few. The histological, histochemical, and electron microscopic studies appear to be indistinguishable, except that the mucosal cell height failed to reach normal values in four of the five patients. Prednisolone may either incompletely protect the mucosal cell from damage or may itself prevent the cell from gaining its full height. In rats treated with similar dosages of prednisolone in respect of body weight, cell height, villous height, and mucosal thickness were all reduced (Wall and Peters, 1970). Metabolic studies of our patients showed improved xylose absorption, but persistent steatorrhoea at a lower level in three of the four patients studied, including the one whose cell height had entered the normal range (case 4). Steatorrhoea depends on the severity and extent of the mucosal change (Stewart et al, 1967). The maximal local dose of prednisolone is achieved in the upper jejunum, and mucosal changes below this level may be less affected because the drug has been absorbed in the jejunum. Further, after dietary treatment, the mucosal response and return of steatorrhoea to normal may take months (Yardley et al, 1962). The present study may have been too short for full remission to occur in all cases.

The mechanism by which prednisolone protects the bowel from the effects of gluten is not clear. In untreated coeliac disease there appears to be a high rate of epithelial cell turnover with increased mitotic counts (Padykula, Strauss, Ladman, and Gardner, 1961) and visible desquamation of the surface cells (Rubin, Ross, Sleisenger, and Weser, 1966). Theories to explain this surface cell damage include deficiency of an enzyme capable of digesting gluten, with consequent accumulation of a substance toxic to the cell (Frazer, 1956), or local hypersensitivity to an antigen contained in gluten (Kowlessar, 1967). Prednisolone may act in several ways to modify these processes. Corticosteroids are known to increase the activity of cellular enzymes (Knox and Greengaard, 1965), and to stabilize the lysosomal membrane (Weissmann, 1964; Gordis and Nitowsky, 1965) preventing liberation of hydrolytic enzymes within the cell. They are also anti-inflammatory, and suppress local hypersensitivity reactions.

In this study, the earliest response of surface cell height to prednisolone was seen after two days of treatment, the calculated normal cell turnover time in man (Bertalanffy and Nagy, 1961). Histochemical and biochemical measurement of mucosal enzyme activity showed a gradual and progressive improvement with treatment. The capacity of the mucosa to hydrolyse gluten peptides in vitro did not return to normal at an earlier stage than the other enzyme activities. Induction or enhancement of peptidase enzymes seem unlikely explanations for the observed structural improvement. On the other hand, there was limited histochemical evidence of early morphological improvement of the lysosomes, and this would support the suggestion of Riecken et al (1966) that an increased rate of lysosomal breakdown may be an important early stage in cellular damage in this condition. The degree of lymphoid infiltration changed slowly with treatment, and did not precede structural improvement, suggesting that the infiltration was a secondary phenomenon.

Evidence for an immunological disorder in coeliac disease includes the clinical observations of a response to corticosteroids, 'gliadin shock' (Krainick, Debatin, Gautier, Tobles, and Velasco, 1958), and the pathological observations of lymphoid atrophy (McCarthy, Fraser, Evans, and Read, 1966), an increased incidence of lymphomatous change (Harris, Cooke, Thompson, and Waterhouse, 1967), immunoglobulin deficiency responding to dietary treat- 
ment (Hobbs and Hepner, 1968), serum and faecal antibodies to gluten (Taylor, Truelove, and Wright, 1964; Herskovic, Katz, and Gryboski, 1968), a heavy infiltrate of lymphoid cells in the damaged bowel, and the presence of a serum factor which may inhibit lymphocyte transformation in vitro (Winter, McCarthy, Read, and Yoffey, 1967). To these we would add an observed tissue response to corticosteroid drugs.

There is now evidence that the response of adult coeliac disease to prednisolone has an anatomical and functional basis comparable with the response achieved by a gluten-free diet, and that withdrawal of either form of treatment rapidly leads to histological relapse. The immunological aspects of the pathogenesis of coeliac disease warrant further study.

We are grateful to Mr. W. Brackenbury for the photomicrographs.

\section{References}

Abe, T., and Shimizu, N. (1964). Histochemical method for demonstrating aldolase. Histochemie, 4, 209-212.

Adlersberg, D., Colcher, H., and Drachman, S. (1951). Studies on the effects of cortisone and pituitary adrenocorticotrophic hormone (ACTH) in the sprue syndrome. Gastroenterology, 19, 674-697.

Barka, T., and Anderson, P. J. (1962). Histochemical methods for acid phosphatase using hezazonium pararosanilin as coupler. J. Histochem. Cytochem., 10, 741-753.

Benson, G. D., Kowlessar, O. D., and Sleisenger, M. H. (1964). Adult celiac disease with emphasis upon response to the gluten-free diet. Medicine (Baltimore), 43, 1-40.

Bertalanffy, F. D., and Nagy, K. P. (1961). Mitotic activity and renewal rate of the epithelial cells of human duodenum. Acta anat. (Basel), 45, 362-370.

Burstone, M. S. (1968). Histochemical comparison of naphthol AS-phosphates for the demonstration of phosphatases. J. nat. Cancer Inst., 20, 601-616.

Crosby, W. H., and Kugler, H. W. (1957). Intraluminal biopsy of the small intestine: the intestinal biopsy capsule. Amer. $J$. dig. Dis., 2, 236-241.

Dicke, W. K. (1950). Coeliakie. Een onderzock naar de nadelige invloed van somnige graansoorten op de lijder aan coeliakie. Thesis. University of Utrecht.

Douglas, A. P., and Booth, C. C. (1970). Digestion of gluten peptides by normal human jejunal mucosa and by mucosa from patients with adult coeliac disease. Clin. Sci., 38 , 11-25.

Frazer, A. C. (1956). Discussion on some problems of steatorrhoea and reduced stature. Proc. roy. Soc. Med., 49, 1009-1013.

French, J. M., Hawkins, C. F., and Smith, N. (1957). The effect of a wheat-gluten-free diet in adult idiopathic steatorrhoea. Quart. J. Med., NS 26, 481-499.

Glenner, G. G., Burtner, H. J., and Brown, G. W. (1957). The histochemical demonstration of monoamine oxidase activity by tetrazolium salts. J. Histochem. Cytochem., 5, 591-600.

Gomori, G. (1952). Microscopic Histochemistry: Principles and Practice; pp. 189-194. University of Chicago Press, Chicago.

Gordis, L., and Nitowsky. (1965). Lysosomes in human cell cultures. Kinetics of enzyme release from injured particles. Exp. Cell Res., 38, 556-569.

Harris, O. D., Cooke, W. T., Thompson, H., and Waterhouse, J. A. H. (1967). Malignancy in adult coeliac disease and idiopathic steatorrhoea. Amer. J. Med., 42, 899-912.

Herskovic, T., Katz, J., and Gryboski, J. D. (1968). Coproant ibodies to gluten in celiac disease. J. Amer. med. Ass., 203, 887-888.

Hess, R., and Pearse, A. G. E. (1958). The histochemistry of indoxyl-esterase of rat kidney with special reference to its cathepsin-like activity. Brit. J. exp. Path., 39, 292-299.

Hobbs, J. R., and Hepner, G. W. (1968). Deficiency of gamma-M globulin in coeliac disease. Lancet, 1, 217-220.

Holt, S. J. (1958). Indigogenic staining methods for esterases. In General Cytochemical Methods. Edited by J. F. Danielli, Vol. 1, pp. 375-398. Academic Press, New York.

Knox, W. E., and Greengard, O. (1965). The regulation of some enzymes of nitrogen metabolism-an introduction to enzyme physiology. Advanc. Enzyme Regulat., 3, 247-313.
Kowlessar, O. S. (1967). Effect of wheat proteins in celiac disease Gastroenterology, 52, 893-897.

Krainick, H. G., Debatin, F., Gautier, E., Tobler, R., and Velasco, J. A. (1958). Additional research on the injurious effect of wheat flour in coeliac disease. I. Acute gliadin reaction (gliadin shock). Helv. paediat. Acta, 13, 432-454.

Lepore, M. J. (1958). Long term or maintainance adrenal steroid therapy in non-tropical sprue. Amer. J. Med., 25, 381-390.

Lowry, O. H., Rosebrough, N. J., Farr, A. L., and Randell, R. J. (1951). Protein measurement with Folin phenol reagent. J. biol. Chem., 193, 265-275.

MacDonald, W. C., Brandborg, L. L., Flick, A. L., Trier, J.S., and Rubin, C. E. (1964). Studies of celiac sprue. IV. The response of the whole length of the small bowel to a glutenfree diet. Gastroenterology, 47, 573-589.

McCarthy, C. F., Fraser, I. D., Evans, K. T., and Read, A. E. (1966). Lymphoreticular dysfunction in idiopathic steatorrhoea. Gut., 7, 140-148.

Nachlas, M. M., Crawford, D. T., and Seligman, A. M. (1957). The histochemical demonstration of leucine aminopeptidase. J. Histochem. Cytochem., 5, 264-278.

Nachlas, M. M., Tsou, K. C., Souza, E. de, Cheng, C. S., and Seligman, A. M. (1957). Cytochemical demonstration of succinic dehydrogenase by the use of a new p-nitrophenyl substituted ditetrazole. J. Histochem. Cytochem., 5, 420436.

Otaki, A. T., Daly, J. R., and Morton-Gill, A. (1967). Observations on oral betamethasone-17-valerate in the treatment of idiopathic steatorrhoea. Gut, 8, 458-462.

Padykula, H. A., Strauss, E. W., Ladman, A. J., and Gardner, F. H. (1961). A morphologic and histochemical analysis of the human jejunal epithelium in non-tropical sprue. Gastroenterology, 40, 735-765.

Pugh, D., and Walker, P. G. (1961). Histochemical localisation of beta-glucuronidase and $\mathrm{N}$-acetyl-beta-glucosaminidase. J. Histochem. Cytochem., 9, $105-106$.

Roe, J. H., and Rice, E. W. (1948). A photometric method for the determination of free pentoses in animal tissues. J. biol. Chem., 173, 507-512.

Riecken, E. O., Stewart, J. S., Booth, C. C., and Pearse, A. G. E. (1966). A histochemical study on the role of lysosomal enzymes in idiopathic steatorrhoea before and during a gluten-free diet. Gut, 7, 317-332.

Rubin, W., Ross, L. L., Sleisenger, M. H., and Weser, E. (1966). An electronmicroscopic study of adult celiac disease. Lab. invest., 15, 1720-1747.

Samloff, M. I., Davis, J. S., and Schenk, E. A. (1965). A clinical and histochemical study of celiac disease before and during a gluten-free diet. Gastroenterology, 48, 155-172.

Scarpelli, D. G., Hess, R., and Pearse, A. G. E. (1958). The cytochemical localisation of oxidative enzymes. I. Diphosphopyridine nucleotide diaphorase and triphosphopyridine nucleotide diaphorase. J. biophys. biochem. Cytol., 4, 747-752.

Spiro, H. M., Filipe, M. I., Stewart, J. S., Booth, C. G., and Pearse, A. G. E. (1964). Functional histochemistry of the small bowel mucosa in malabsorption syndromes. Gut, 5 , 145-154.

Stewart, J. S., Pollock, D. J., Hoffbrand, A. V., Mollin, D. L., and Booth, C. C. (1967). A study of proximal and distal intestinal structure and absorptive function in idiopathic steatorrhoea. Quart. J. Med., NS, 36, 425-444.

Taylor, K. B., Truelove, S. C., and Wright, R. (1964). Serologic reaction to gluten and cow's milk proteins in gastrointestinal disease. Gastroenterology, 46, 99-108.

Wachstein, M., and Meisel, E. (1956). On the histochemical demonstration of glucose- 60 phosphatase. J. Histochem. Cytochem., 4, 592.

Wachstein, M., and Meisel, E. (1957). Histochemistry of hepatic phosphatases at physiologic pH. Amer. J. clin. Path., 27, 13-23.

Wall, A. J., and Peters, T. J. (1970). Effect of prednisolone on the small intestinal mucosa of the rat. (In preparation).

Weissman, G. (1964). Localization and stabilization of lysosomes. Fed. Proc., 23, 1038-1044.

Whitby, L. G., and Lang, D. (1960). Experience with the chromic oxide method of fecal marking in metabolic balance investigations on humans. J. clin. Invest., 39, 854-863.

Wooton, I. D. P. (1964). Micro-analysis in Medical Biochemistry, 4th ed., pp. 193-195. Churchill, London.

Winter, G. C. B., McCarthy, C. F., Read, A. E., and Yoffey, J. M. (1967). Development of macrophages in phytohaemagglutinin cultures of blood from patients with idiopathic steatorrhoea and with cirrhosis. Brit. J. exp. Path., 47, 66-80.

Yardley, J. H., Bayless, T. M., Norton, J. H., and Hendrix, T. R. (1962). Celiac disease. A study of the jejunal epithelium before and after a gluten-free diet. New Engl.J. Med., 267, 1173-1179. 